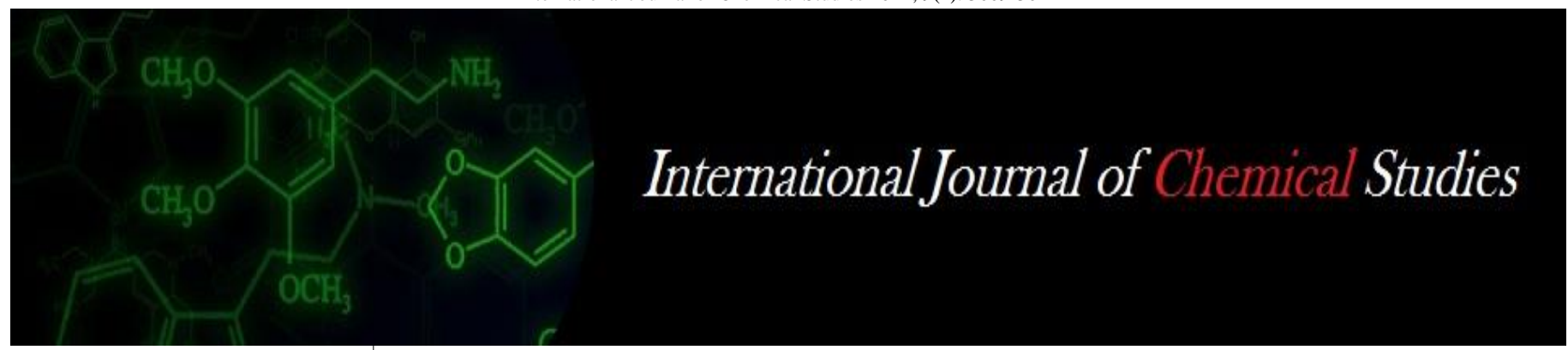

P-ISSN: 2349-8528

E-ISSN: 2321-4902

www.chemijournal.com

IJCS 2021; 9(1): 3009-3011

(C) 2021 IJCS

Received: 08-11-2020

Accepted: 18-12-2020

\section{Kalambe JD}

M.Sc., Department of

Agronomy, College of

Agriculture, VNMKV Parbhani,

Maharashtra, India

\section{Bhalerao GA}

Associate Professor, Department

of Agronomy, College of

Agriculture VNMKV Parbhani,

Maharashtra, India

\section{Mirza IAB}

Assistant Professor, Department of Agronomy, College of

Agriculture VNMKV Parbhani,

Maharashtra, India

\section{Jawale SS}

M.Sc., Department of

Agronomy, College of

Agriculture, VNMKV Parbhani,

Maharashtra, India
Corresponding Author:

Kalambe JD

M.Sc., Department of

Agronomy, College of

Agriculture, VNMKV Parbhani,

Maharashtra, India

\section{Effect of growth regulators, seaweed extract and potassium nitrate on growth, yield and quality of soybean (Glycine max (L.) Merrill)}

\author{
Kalambe JD, Bhalerao GA, Mirza IAB and Jawale SS
}

DOI: https://doi.org/10.22271/chemi.2021.v9.i1ap.11686

\begin{abstract}
The field investigation entitled "Effect of growth regulators, seaweed extract and potassium nitrate on growth and yield of soybean (Glycine $\max$ (L.) Merrill)" was conducted at experimental farm, Department of Agronomy, College of Agriculture, VNMKV, Parbhani during kharif 2018-19. The experiment was laid out in a randomized block design with seven treatments and three replications with a view to find out the influence of different growth regulators, seaweed extract and potassium nitrate applied at flowering and pod developing stage of soybean. From the result it was revealed that application of seaweed extract-20\% at flowering and developing stage recorded higher plant height, more number of functional leaves, higher leaf area, higher number of branches, higher dry matter accumulation, higher seed yield, higher oil content and oil yield, higher protein content and protein yield, and it was at par with $\mathrm{GA}_{3}-100 \mathrm{ppm}$ and Salicylic acid-50ppm.
\end{abstract}

Keywords: Soybean, growth regulators, seaweed extract, potassium nitrate, growth, yield, quality

\section{Introduction}

Soybean has been principal food crop since long time as it produce 2-3 times more high quality protein per hectare than other pulses and cholesterol free oil. It is an excellent health food as it contains $40-42 \%$ quality protein, $23 \%$ carbohydrates and $20 \%$ cholesterol free oil. It is the cheapest and main source of dietary protein of majority of vegetarian (hence it is known as poor man's meat). In Maharashtra soybean production during kharif 2018 was 18.22 lakhs ton from an area 17.40 lakh hectares with the productivity of $967 \mathrm{~kg} \mathrm{ha}^{-1}$ (Anonymous 2018) [2].

Soybean, a wonder legume has high nutritive value and has manifold uses in agriculture, medicine and industrial sector. It is economically profitable as compared to cereals and other oilseed crops. It is highly remunerative crop with comparatively less input demand. Due to its short duration (85 to 90 days) fits well as an intercrop and photo insensitiveness of crops made it as suitable crops made in double cropping system. Being a leguminous crop, capable of fixing atmospheric nitrogen to an extent 65 to $100 \mathrm{~kg} \mathrm{ha}^{-1}$ and help to improve the soil fertility. The area under soybean cultivation is increasing due to some reason such as soybean is short duration crop (90-110 days) and good market price with its higher productivity compared to other pulses. It can be processed easily for different products viz., soy cheese, soy milk, soy protein, soy yogurt, soybean oil, soy nut. Soybean also used for making the soy ink, soy paint and soy molasses. It can give a boost to the food-processing industry in rural areas of India. Soybean is miracle crop of $21^{\text {st }}$ century which possesses potential to revolutionize Indian economy by correcting the health of human being and soil.

Seaweed extract contains major and minor nutrients, amino acids, vitamins, cytokinins, auxin and abscisic acid like growth promoting substances (Mooney and Van Staden, 1986) ${ }^{[7]}$. The beneficial effect of seaweed extract application is as a result of many componants that may work synergistically at different concentrations, although the mode of action still remains unknown (Fornes et al., 2002) ${ }^{[4]}$. Marine bioactive substances extracted from marine algae are used in agricultural crops, and many beneficial effects in the terms of yield and quality have been reported. Liquid extracts obtained from sea weed extracts have recently gained importance as foliar sprays for many crops including various grasses, cereals, flowers and 
vegetable species (Crouch and Van Staden, 1994).

In recent years, use of seaweed extracts have gained in popularity due to their potential use in organic and sustainable agriculture, especially in rainfed crops, as a means to avoid excessive fertilizer applications and to improve mineral absorption. Unlike, chemical fertilizers, extracts derived from seaweeds are biodegradable, non-toxic, non-polluting and non-hazardous to humans, animals and birds (Dhargalkar and Pereira, 2005) ${ }^{[3]}$.

\section{Materials and Methods}

\subsection{Site description}

A field experiment was conducted at experimental farm, Department of Agronomy, VNMKV, Parbhani, MH, during kharif season 2018. The soil of the experimental field was black cotton. The experimental site is under subtropical climatic condition.

\subsection{Experimental treatments}

The experiment was consisted of seven treatments viz., Salicylic acid-50ppm $\left(\mathrm{T}_{1}\right), \mathrm{GA}_{3}-100 \mathrm{ppm}\left(\mathrm{T}_{2}\right)$, Nitrobenzene400ppm ( $\left.\mathrm{T}_{3}\right)$, NAA-20ppm $\left(\mathrm{T}_{4}\right)$, Seaweed extract-20\% $\left(\mathrm{T}_{5}\right)$, Potassium nitrate-2\% $\left(\mathrm{T}_{6}\right)$, Water spray $\left(\mathrm{T}_{7}\right)$ and two stages of application i.e. at the time of flowering and pod developing stage.

\subsection{Seeds, design and plot size}

The variety MAUS-71 was used and experiment was arranged in Randomized Block Design with three replications and comprised of 21 unit plots. The gross and net size of each plot was $5.4 \mathrm{~m} \mathrm{x} 4.5 \mathrm{~m}, 4.5 \mathrm{~m}$ x $4.0 \mathrm{~m}$, respectively.

2.4 Fertilizer application and sowing of seeds in the plot Urea, Single super phosphate (SSP), Muriate of potash (MOP) were used as a source of nitrogen, phosphorous, potassium, respectively. The fertilizers urea, SSP, MOP were applied as per recommendation.

\subsection{Application of treatments}

All the growth regulators, seaweed extract and potassium nitrate are applied in two sprayings as foliar spray, $1^{\text {st }}$ spraying at the time of flowering and $2^{\text {nd }}$ spraying at pod developing stage.

\subsection{Statistical analysis}

Collected data on different parameters were statistically analyzed by using "analysis of variance method (ANOVA)" (Panse and Sukhatme, 1967) ${ }^{[8]}$.

\section{Results and Discussion}

3.1 Effect of growth regulators, seaweed extract and potassium nitrate on growth and growth attribute of soybean

Foliar application of different growth regulators, seaweed extract and potassium nitrate exposed variation on growth characteristics of soybean such as plant height, number of functional leaves, leaf area, number of branches, total dry matter accumulation. Among all the treatments application of treatment $\mathrm{T}_{5^{-}}$Seaweed extract-20\% to soybean crop at flowering and pod developing stage showed better result (Table 1) with respect to plant height $(49.90 \mathrm{~cm})$, number of functional leaves (23.57), leaf area $\left(9.60 \mathrm{dm}^{2}\right)$, number of branches (6.18), mean dry matter accumulation $(16.73 \mathrm{~g})$ and at par with treatment $\mathrm{T}_{2}-\mathrm{GA}_{3}-100 \mathrm{ppm}$ and $\mathrm{T}_{1}-$ Salicylic acid$50 \mathrm{ppm}$. However lower values were recorded in treatment $\mathrm{T}_{7^{-}}$ Water spray. Similar trend of observation observed by Patel $e t$ al. (2008) ${ }^{[9]}$, Jagadeshwari et al. (2004) ${ }^{[5]}$.

Table 1: Effect of growth regulators, seaweed extract and potassium nitrate on growth and growth attribute of soybean as influenced by different treatments

\begin{tabular}{|c|c|c|c|c|c|}
\hline Treatment details & Plant height $(\mathbf{c m})$ & Number of functional leaves & Leaf area $\left(\mathbf{d m}^{2}\right)$ & Number of branches & Dry matter $(\mathbf{g})$ \\
\hline $\mathrm{T}_{1}$ - Salicylic Acid-50 ppm & 43.22 & 21.97 & 8.27 & 5.40 & 14.40 \\
\hline $\mathrm{T}_{2}-\mathrm{GA}_{3}-100 \mathrm{ppm}$ & 47.28 & 22.86 & 9.02 & 5.98 & 15.40 \\
\hline $\mathrm{T}_{3}-$ Nitrobenzene-400 ppm & 38.23 & 19.81 & 7.08 & 4.93 & 12.60 \\
\hline $\mathrm{T}_{4}$ - NAA- 20 ppm & 37.20 & 16.13 & 6.41 & 4.71 & 12.40 \\
\hline $\mathrm{T}_{5}-$ Seaweed extract-20\% & 49.90 & 23.57 & 9.60 & 6.18 & 16.73 \\
\hline $\mathrm{T}_{6}$ - KNO ${ }_{3}-2 \%$ & 41.56 & 13.74 & 5.86 & 3.22 & 11.05 \\
\hline $\mathrm{T}_{7}$ - Water spray & 32.02 & 13.28 & 5.48 & 3.16 & 9.40 \\
\hline S.E.(m) \pm & 2.20 & 1.07 & 0.44 & 0.37 & 0.84 \\
\hline C.D. at 5\% & 6.79 & 3.31 & 1.36 & 1.13 & 2.61 \\
\hline General mean & 41.34 & 18.77 & 7.39 & 4.80 & 13.24 \\
\hline
\end{tabular}

3.2 Effect of growth regulators, seaweed extract and potassium nitrate on yield and yield attributes of soybean. The foliar application of different growth regulators, seaweed extract and potassium nitrate showed variation on yield characteristics of soybean such as number of pods plant ${ }^{-1}$, Number of seeds plant ${ }^{-1}$, Seed yield plant ${ }^{-1}(\mathrm{~g})$, Seed index $(\mathrm{g})$ (Weight of 100 seeds), Seed yield kg ha ${ }^{1}$, Straw yield kg ha-1, Harvest index $\%$. Among all the treatments application of $\mathrm{T}_{5^{-}}$ seaweed extract-20\% increased all the yield parameters except harvest index and being significantly better (Table 2). The highest number of pods plant ${ }^{-1}$ (32.97), Number of seeds plant $^{-1}$ (72.83), Seed yield plant ${ }^{-1}(6.57 \mathrm{~g})$, Seed index (9.62 g) Seed yield $\left(2307 \mathrm{~kg} \mathrm{ha}^{1}\right)$, Straw yield $\left(3055 \mathrm{~kg} \mathrm{ha}^{-1}\right)$ were observed at seaweed extract@400ppm which was significantly higher over all the treatments but highest harvest index (43.28\%) was observed in $\mathrm{T}_{2}-\mathrm{GA}_{3}-100 \mathrm{ppm}$., and at par with treatment $\mathrm{T}_{2}-\mathrm{GA}_{3}-100 \mathrm{ppm}$ and $\mathrm{T}_{1}-$ Salicylic acid-50ppm. However lower values were recorded in treatment $\mathrm{T}_{7}$-Water spray. Similar trend of observation observed by by Kavitha et al. (2008) ${ }^{[6]}$. Agwane and Parhe (2015) ${ }^{[1]}$, Kumar et al. $(2018)^{[12]}$. 
Table 2: Effect of growth regulators, seaweed extract and potassium nitrate on yield and yield attributes of soybean as influenced by different treatments

\begin{tabular}{|c|c|c|c|c|c|c|c|c|}
\hline Tr. No & Treatments & $\begin{array}{c}\text { No. of pods } \\
\text { plant }^{-1}\end{array}$ & $\begin{array}{c}\text { No. of seeds } \\
\text { plant }^{-1}\end{array}$ & $\begin{array}{l}\text { Seed yield } \\
\text { plant }^{-1}(\mathrm{~g})\end{array}$ & \begin{tabular}{|c|} 
Seed index \\
$(\mathrm{g})$
\end{tabular} & $\begin{array}{c}\text { Seed yield } \\
\mathrm{kg} \mathrm{ha}^{-1}\end{array}$ & $\begin{array}{c}\text { Straw yield } \\
\text { kg ha }^{-1}\end{array}$ & $\begin{array}{l}\text { Harvest } \\
\text { index \% }\end{array}$ \\
\hline $\mathrm{T}_{1}$ & Salicylic Acid-50 ppm & 29.09 & 68.50 & 5.70 & 8.90 & 2014 & 2877 & 42.03 \\
\hline $\mathrm{T}_{2}$ & $\mathrm{GA}_{3}-100 \mathrm{ppm}$ & 30.29 & 70.90 & 6.20 & 9.39 & 2246 & 2943 & 43.28 \\
\hline $\mathrm{T}_{3}$ & Nitrobenzene-400 ppm & 27.05 & 63.30 & 5.12 & 8.37 & 1909 & 2661 & 41.78 \\
\hline $\mathrm{T}_{4}$ & NAA-20 ppm & 26.24 & 60.04 & 4.83 & 8.02 & 1821 & 2520 & 41.95 \\
\hline $\mathrm{T}_{5}$ & Seaweed extract-400ppm & 32.97 & 72.83 & 6.57 & 9.62 & 2307 & 3055 & 43.02 \\
\hline $\mathrm{T}_{6}$ & $\mathrm{KNO}_{3}-2 \%$ & 25.41 & 58.16 & 4.59 & 7.98 & 1722 & 2455 & 41.22 \\
\hline $\mathrm{T}_{7}$ & Water spray & 24.00 & 49.90 & 3.17 & 7.05 & 1509 & 2235 & 40.30 \\
\hline \multicolumn{2}{|r|}{ S.E. $(\mathrm{m}) \pm$} & 1.61 & 2.94 & 0.37 & 0.50 & 111.91 & 155.63 & - \\
\hline \multicolumn{2}{|r|}{ C.D. at $5 \%$} & 4.96 & 9.07 & 1.14 & NS & 344.03 & 479.52 & - \\
\hline \multicolumn{2}{|r|}{ General mean } & 27.86 & 63.38 & 5.17 & 8.44 & 1932.57 & 2678 & 42.04 \\
\hline
\end{tabular}

3.3 Effect of growth regulators, seaweed extract and potassium nitrate on quality parameters of soybean

The foliar application of different growth regulators, seaweed extract and potassium nitrate showed variation on quality parameters of soybean such as oil content $(\%)$, Oil yield $(\mathrm{kg}$ $\left.\mathrm{ha}^{-1}\right)$, Protein content $(\%)$ and Protein yield $\left(\mathrm{kg} \mathrm{ha}^{-1}\right)$.

The oil content (\%) was not influenced significantly with the application of different treatments (Table 3). While, mean oil yield ( $\left.373.05 \mathrm{~kg} \mathrm{ha}^{-1}\right)$ was found to be statistically significant with the application of different treatments. Treatment $\mathrm{T}_{5^{-}}$ Seaweed extract-20\% produced the highest value of oil content $(19.96 \%)$ whereas, it also recorded significantly higher oil yield $\left(460.40 \mathrm{~kg} \mathrm{ha}^{-1}\right)$. Application of seaweed extract helped in increasing mean oil yield $\left(\mathrm{kg} \mathrm{ha}^{-1}\right)$. Rathore et al. (2009) also recorded similar kind of results.

The effect of different treatments on protein content $(\%)$ was found to be non-significant, whereas, mean protein yield $(\mathrm{kg}$ $\mathrm{ha}^{-1}$ ) was found to be statistically significant (Table 3). Treatment $\mathrm{T}_{5}$ - Seaweed extract-20\% recorded higher protein content $(39.98 \%)$ and protein yield $\left(910.00 \mathrm{~kg} \mathrm{ha}^{-1}\right)$. Similar results were reported by Renuka Bai et al. (2007) ${ }^{[11]}$.

Table 3: Oil content (\%), oil yield $\left(\mathrm{kg} \mathrm{ha}^{-1}\right)$ and protein content (\%), protein yield $\left(\mathrm{kg} \mathrm{ha}^{-1}\right)$ as influenced by various treatments

\begin{tabular}{|c|c|c|c|c|c|}
\hline Sr. No. & Treatments & Oil content $(\%)$ & Oil yield (kg ha-1) & Protein Content (\%) & Protein yield $\left(\mathrm{kg} \mathrm{ha}^{-1}\right)$ \\
\hline $\mathrm{T}_{1}$ & Salicylic Acid-50 ppm & 19.71 & 396.95 & 38.66 & 773.33 \\
\hline $\mathrm{T}_{2}$ & $\mathrm{GA}_{3}-100 \mathrm{ppm}$ & 19.83 & 445.38 & 39.89 & 890.30 \\
\hline $\mathrm{T}_{3}$ & Nitrobenzene-400 ppm & 19.60 & 364.14 & 38.60 & 716.67 \\
\hline $\mathrm{T}_{4}$ & NAA-20 ppm & 19.67 & 349.94 & 38.49 & 680.33 \\
\hline $\mathrm{T}_{5}$ & Seaweed extract-400ppm & 19.96 & 460.40 & 39.98 & 910.00 \\
\hline $\mathrm{T}_{6}$ & $\mathrm{KNO}_{3}-2 \%$ & 19.35 & 320.01 & 38.40 & 653.33 \\
\hline $\mathrm{T}_{7}$ & Water spray & 19.02 & 279.57 & 38.26 & 560.25 \\
\hline \multicolumn{2}{|r|}{ S.E. $(m) \pm$} & 0.30 & 32.93 & 0.52 & 60.03 \\
\hline \multicolumn{2}{|r|}{ C.D at $5 \%$} & NS & 101.47 & NS & 184.96 \\
\hline \multicolumn{2}{|r|}{ General mean } & 19.59 & 373.77 & 38.89 & 740.60 \\
\hline
\end{tabular}

\section{Conclusion}

The foliar application of growth regulators, seaweed extract and potassium nitrate at flowering and pod developing stage performed well growth, yield and quality parameters of soybean as compared to water spray but application of seaweed extract-20\% at flowering and pod developing stage increase growth, yield and quality parameters as compare to other treatments and over water spray.

From the above results and discussion it may be concluded that, application of seaweed extract-20\% at flowering and pod developing stage would be promising practice for soybean growth, yield and quality parameters.

\section{References}

1. Agwane RB, Parhe SD. Effect of seed priming on crop growth and seed yield of soybean (Glycine $\max$ L. Merrill). The Bioscan 2015;10:265-270.

2. Anonymous. Area, Production, Productivity estimate by Soybean Processors Association of India (SOPA) databank, source: oilseed- world markets and trade, a USDA publication, during 2018-19. www.sopa.org (Date- 8/5/2019).

3. Dhargalkar VK, Pereira N. Seaweed: Promising plant of the millennium. Science and culture 2005;71:60-66.

4. Fornes F, Sanchez-Perales M, Guadiola JL. Effect of a seaweed extract on the productivity of 'de Nules' Clementine mandarin and navelina orange. Botanica Marina 2002;45:486-489.

5. Jagadeshwari P, Sharma SP, Dadlani M. Effect of different chemicals on traits favouring outcrossing and optimization of
$\mathrm{GA}_{3}$ for seed production of cytoplasmic male sterile line in hybrid rice. Seed science and technology 2004;32:473-483.

6. Kavitha MP, Ganeshraja V, Paulpandi VK. Effect of foliar spraying of sea weed extract on growth and yield of rice (Oryza sativa L.) Agricultural Science Digest 2008;28(2):127-129.

7. Mooney PA, Van Staden J. Algae and Cytokinines. Journal of Plant Physiology 1986;123:1-2.

8. Panse VG, Sukhatme PV. Statistical methods for Agricultural Workers. ICAR, New Delhi 1967.

9. Patel KC, Patel KP, Kandoria HK, Jetani KL, Ramani. Yield of uptake of micronutrient by groundnut influenced by foliar application of seaweed liquid fertilizer under rainfed condition of Jamkhambhaliya, Saurashtra region. An Asian Journal of soil science 2008;3(2):252-256.

10. Rathore SS, Chaudhary DR, Boricha GN, Ghosh A, Bhatt BP, Zodpe ST et al. Effect of sea weed extract on growth, yield and nutrient uptake of soybean (Glycine max) under rainfed conditions. South African Journal of Botany 2008;75(2009):351-355.

11. Renuka Bai N, Laila Banu NR, Prakash JW, Jaquilin Goldi S. Effects of Asparagopsis taxiformis extract on the Growth and Yield of Phaseolus aureus. Journal of Basic and App. Bio 2007;1(1):6-11.

12. Kumar AN, Sakthivel E, Subramanian R, Kalpana P, Janaki, Rajesh P. Influence of foliar spray of nutrients and plant growth regulators on physiological attributes and yield of finger millet (Eleusine coracana (L.) Gaertn.) International Journal of Chemical Studies 2018;6(3):2876-2879. 